\title{
NVA: A Value Addition Measure For Capital Project Evaluation
}

Bhavesh M. Patel, (Email: bmpatel@hotmail.com), Myers University

U. Rao Cherukuri, (Email: rao@stan.csustan.edu), California State University, Stanislaus

\begin{abstract}
Corporate financial objective of stockholder wealth maximization and use of discounted cash flow methods for evaluation of capital projects are two of the well-accepted tenets of financial management. Present project evaluation methods, including the Net Present Value (NPV) technique, do not fully meet the stockholder wealth maximization criteria. This paper attempts to scrutinize the relevance of the NPV method in achieving the wealth maximization objective and suggests an alternative value addition measure, named Net Value Added (NVA). In the NPV method, all cash flows pertaining to a project are lumped together and discounted with one single rate, the weighted average cost of capital. The NVA method advocates that a project's residual (net of its debt servicing) cash flows that belong to stockholders should be classified on the basis of their end-use, viz., equity servicing, capital maintenance, and value creating surplus cash flows. As the risks associated with each of these three stockholders' cash flows are not the same, they are separately discounted at appropriate rate depending upon the associated risk. Power of time (n) is assigned only to real risk-free rate of return and inflation premium to discount equity servicing and capital maintenance cash flows that are subject to exponential growth over time but not to the risk premium.
\end{abstract}

\section{Introduction}

orporate financial objective of stockholder wealth maximization and use of discounted cash flow (DCF) techniques in evaluating capital investments are two of the important tenets of financial management that got wider consensus among academicians. Net present value method (NPV) among the DCF measures is considered to be the most suitable method congruent with the corporate financial objective of stockholder wealth maximization.

Maximizing the difference between a firm's market value of equity and its book value of equity capital maximizes stockholder wealth. This difference, which is termed as market value added (MVA) is tied via economic value added (EVA) to the widely used DCF project evaluation technique, NPV. EVA which is the residual wealth that a firm creates from several capital projects in a given year after accounting for the opportunity cost of invested capital "is a link in the chain that begins with the NPV of an individual project and ends with the firm's MVA." Of course, MVA depends more on expected future performance than on historical EVAs. (Brigham et al., 1996 and 1999).

This paper attempts to scrutinize the relevance of the NPV method in achieving the corporate objective of stockholder wealth maximization and suggests an alternative measure of value addition. The suggested alternative is Net Value Added (NVA), which measures the creation of value to stockholders through corporate financing and investment decisions.

Readers with comments or questions are encouraged to contact the authors via email. 


\section{Corporate Financial Objective and Project Evaluation Methods}

As stated, stockholder wealth maximization is the widely accepted corporate financial objective. Wealth is differentiated from profit on two counts, time and risk. Recognition of time and risk would warrant use of cash flows rather than profits in making value-maximizing investments. Financial evaluation of investment proposals is carried out prudently through discounted cash flow (DCF) techniques, basically through net present value (NPV) and internal rate of return (IRR), with quite a few variants of each of them. For example, profitability index (PI) and adjusted present value (APV) are variants of NPV, and modified internal rate of return (MIRR) is the variant of IRR. PI was developed to give a relative rate of appreciation in value over investment rather than the absolute value that NPV gives. APV and MIRR attempt to address the issue of appropriate discount rate.

Theoretical contributions of Tuttle and Litzenberger (1968), Robert Hamada (1969) and others integrating capital budgeting theory with the Sharpe (1964) and Lintner (1965) capital asset pricing model (CAPM) have provided insights into the relationship between costs of capital and risk. Hamada has provided the methodology to separate risk premium into two parts: business and financial risk premiums. He combined the CAPM with the Modigliani and Miller (1963) after-tax model of capital structure to obtain the following expression for KsL, the cost of equity to a leveraged firm:

$$
\begin{aligned}
\mathrm{KsL} & =\text { Risk-free Rate } & + \text { Business Risk Premium } & + \text { Financial Risk Premium } \\
& =\mathrm{K}_{\mathrm{RF}} & +\left(\mathrm{K}_{\mathrm{M}}-\mathrm{K}_{\mathrm{RF}}\right) \times \mathrm{b}_{\mathrm{U}} & +\left(\mathrm{K}_{\mathrm{M}}-\mathrm{K}_{\mathrm{RF}}\right) \times \mathrm{b}_{\mathrm{U}} \times(1-\mathrm{T})(\mathrm{D} / \mathrm{S})
\end{aligned}
$$

where: $\mathrm{K}_{\mathrm{RF}}=$ risk free rate, $\mathrm{K}_{\mathrm{M}}=$ market return, $\mathrm{T}=$ tax rate, $\mathrm{D} / \mathrm{S}=$ debt equity ratio, and $\mathrm{b}_{\mathrm{U}}$ is the beta coefficient of the unleveraged (all equity) firm.

Hamada partitioned the required return on a stock of a leveraged firm into three parts: $\mathrm{K}_{\mathrm{RF}}=$ the risk free rate compensating equity investors for the time value of money; $\left(\mathrm{K}_{\mathrm{M}}-\mathrm{K}_{\mathrm{RF}}\right) \times \mathrm{b}_{\mathrm{U}}$ reflecting premium for business risk, and $\left(\mathrm{K}_{\mathrm{M}}-\mathrm{K}_{\mathrm{RF}}\right) \times \mathrm{b}_{\mathrm{U}} \times(1-\mathrm{T})(\mathrm{D} / \mathrm{S})$ compensating for financial risk. In the absence of financial leverage, equity investors would receive only risk free rate and business risk premium.

We consider net market capitalization as the measure of wealth in developing the theme of this paper. It is widely accepted that NPV of a capital project measures the addition to the market capitalization of a firm. We believe that NPV fails in fully measuring true value of wealth creation from investment projects. As an alternative, we advocate the NVA method while simultaneously pointing out the limitations of the NPV method.

\section{Issues Addressed}

This paper advocates NVA as the better value creation measure, which is devoid of the limitations of the NPV technique discussed below.:

1. NPV method follows the principle of 'separation of investment decisions from financing decisions' and considers project's cash flows for discounting purposes. As project's cash flows belong to both types of suppliers of long-term funds their discounted value cannot be a true measure of shareholder wealth. We advocate deducting debt cash flows from the project's cash flows to get those cash flows that exclusively belong to stockholders.

2. As financing is considered an issue independent of investment, the NPV method does not take into account the debt-repayment pattern. It is a prudent business practice to service debt from the cash flows of a project for which the debt is obtained. It is beneficial to properly structure the debt, as it will have an impact on the creation of firm's value, though cost of debt might not change. This paper shows that debt repayment pattern has significant impact on the value creation.

3. This paper also advocates that the residual cash flows that belong to the stockholders should be classified on the basis of their end-use. They are divided into three parts, viz., (a) cash flows for servicing the equity capital, (b) cash flows for maintenance of capital, and (c) surplus cash flows that create value.

4. NPV method prescribes the use of a single discount rate, viz., the weighted average cost of capital 
(WACC). The risk implication of a project is captured in the cost of funds. APV method suggests the application of separate rates of discount depending upon the risk associated with the different parts of project's cash flows. Note that the risk associated with each of the three parts of the stockholders' cash flow stream mentioned earlier (in 3 above) is not the same. These three parts are, therefore, not combined into one for the calculation of NVA. They need to be discounted at appropriate rates depending upon the associated risk. The application of a single discount rate in calculating NPV is unsuitable in measuring the value creation for one more reason. The discount rate has three components in it, namely real risk-free rate, inflation premium for maintenance of capital, and risk premium.

5. $\quad$ In calculating NPV, power of time $n$ (compounding / discounting) is assigned to a single discount rate, viz., the firm's weighted average cost of capital, $\mathrm{K}_{\mathrm{a}}$. The power of time can be assigned if the cash flow series are subject to the exponential growth over time. All the components of cost of capital are not subject to the exponential growth over time. One would notice that the real rate of return (r) and inflation premium $(h)$, are subject to the time value of money while risk premium $\left(\mathrm{R}_{\mathrm{p}}\right)$ is not. Thus the power of time can be assigned to only the first two components of the required rate of return, which are subject to exponential growth over time. NVA takes this aspect into account.

\section{Presentation of Issues}

The theme of the paper is developed around a hypothetical example. All the variables that are required for addressing the issues are given in Table 1. The basic framework is also presented in the following pages before setting to arrive at the NVA. Finally, the NVA calculations are shown.

\section{Example}

Let us take an example of a project with a five-year life to demonstrate the NVA method. The project is assumed to require an initial outlay of $\$ 108,000$, fifty percent of which is financed by debt at an after-tax interest rate of $7.01 \%$. Five debt repayment patterns are explored paying off the $\$ 54,000$ debt by the end of the project's life.

Table 1

Variables, their Notations and Values Used in the Example

\begin{tabular}{|l|c|c|}
\hline Sacrifice value of money (real risk-free rate of return) & $\mathrm{r}$ & $1.80 \%$ \\
Premium for inflation & $\mathrm{h}$ & $2.40 \%$ \\
$\begin{array}{l}\text { Premium for degree of operating leverage (DOL) } \\
\text { (i.e., compensation for business risk) }\end{array}$ & $\mathrm{d}$ & $2.70 \%$ \\
$\begin{array}{l}\text { Premium for degree of financial leverage (DFL) } \\
\text { (i.e., compensation for financial risk) }\end{array}$ & $\mathrm{f}$ & $1.00 \%$ \\
\hline Corporate Tax rate applicable & $\mathrm{t}$ & $40.00 \%$ \\
\hline Debt-Equity Ratio: & & $1: 1=50: 50$ \\
\hline Debt repayment in equal amounts under five options by the end of project life & \\
\hline
\end{tabular}

After-tax net cash inflows are expected to be $\$ 30,000$ per year in years 1 through 4 and $\$ 20,000$ in year 5 (see Table 4). Variables used in the example and their assumed values are given in Table 1 and required computations are shown in Tables 2, 3 and 4. It should be noted that the rates of return given in Table 1 are what investors would expect in the absence of inflation and tax. Component wise break up of costs of funds is given so that suitable parts of cost of capital can be recognized for discounting different parts of stockholders' cash flows.

A new project may change the risk profile of a business. Even when we consider a change in the risk profile in our example the validity of the NVA method would hold. In that case we will have to work out the marginal cost of capital (MCC) and use its break-up components as the discount rates. To avoid this unnecessary complication we assume that the project in our example will not change the risk profile of the business. 


\section{Framework}

The calculation of NVA necessitates us to look at: (a) debt-servicing pattern for finding the stockholders' cash flows; and (b) break-up components of cost of debt, cost of equity, and weighted average cost of capital for discounting stockholders' cash flows.

Each segment of stockholders' cash flows is discounted at the appropriate component cost of equity to get NVA. The initial calculation of NVA is based on the net income (NI) theory of capital structure, which postulates that cost of equity does not change with the reduction in the debt-equity ratio, while average cost of capital declines. Subsequently, net operating income (NOI) theory is assumed and NVA is worked out. Cost of equity can be considered on the basis of any capital structure theory that one believes in. Though the application of NI theory, NOI theory, and traditional theory of capital structure would give different costs of equity at varying debt-equity ratios, the NVA method offers superior results than NPV. And it also provides scope for evaluating financing options for value maximization. As such NVA is consistent with the value maximization objective of the firm.

\subsection{Debt Servicing Schedule}

Servicing of debt would consume a part of the project's cash flows. It would depend on the terms and conditions contracted with the lender. In the present example we consider five alternative debt repayment schedules over time. Table 2 shows the $\$ 54,000$-debt repayment starting at different years during the project's life and the resultant alternative debt servicing cash flows.

Table 2

Debt Servicing Schedule (\$54,000 @ 7.01\% Post-tax)

\begin{tabular}{|c|c|c|c|c|c|}
\hline \multirow{3}{*}{ Year } & \multicolumn{5}{|l}{$\begin{array}{l}\text { Debt (Cash Flow) Servicing Schedule under Different Repayment Options (Interest and equal install- } \\
\text { ments of Principal) }\end{array}$} \\
\cline { 2 - 6 } & $\begin{array}{c}\text { \$50K single } \\
\text { installment at the } \\
\text { end of Y5 (in \$) }\end{array}$ & $\begin{array}{c}\text { \$25K Equal } \\
\text { installments in last } \\
\text { 2 years (in \$) }\end{array}$ & $\begin{array}{c}\text { \$16 2/3K Equal } \\
\text { installments in last } \\
\text { 3 years (in \$) }\end{array}$ & $\begin{array}{c}\text { \$12.5K Equal in- } \\
\text { stallments in last } \\
\text { 4 years (in \$) }\end{array}$ & $\begin{array}{c}\text { \$10K Equal } \\
\text { installments in } \\
5 \text { years (in \$) }\end{array}$ \\
\hline 1 & 3,784 & 3,784 & 3,784 & 3,784 & 14,584 \\
2 & 3,784 & 3,784 & 3,784 & 17,784 & 13,827 \\
3 & 3,784 & 3,784 & 21,784 & 16,338 & 13,071 \\
4 & 3,784 & 30,784 & 20,523 & 15,392 & 12,314 \\
5 & 57,784 & 28,892 & 19,261 & 14,446 & 11,557 \\
\hline
\end{tabular}

\subsection{Component-wise Cost of Funds}

The calculation of each component of cost of debt as well as equity is essential for proper discounting of project cash flows. The calculation of the component-wise rates and the total rates for cost of debt, $\mathrm{K}_{\mathrm{d}}$, cost of equity, $K_{e}$, and weighted average cost of capital, $K_{a}$ are given below:

\subsubsection{Cost of Debt}

Using the conventional equation of calculating cost of debt, we get the following value of $\mathrm{K}_{\mathrm{d}}$ :

$\mathrm{K}_{\mathrm{d}}=\mathrm{h}+\{(1+\mathrm{h}) \times(\mathrm{r}+\mathrm{d})\}$

$\mathrm{K}_{\mathrm{d}}=\{0.024+1.024 \times(0.018+0.027)=7.01 \%$ 
Equation 1 essentially gives components of the cost of debt as shown below:

\begin{tabular}{|c|c|c|c|c|}
\hline $\mathrm{R}_{\mathrm{Dh}}=$ & Inflation premium on debt & $=\mathrm{h}$ & & $=2.40 \%$ \\
\hline $\mathrm{R}_{\mathrm{Dr}}=$ & $\begin{array}{l}\text { Rate of return (sacrifice value) on } \\
\text { borrowed funds }\end{array}$ & $=(1+h) \times r$ & $=(1+0.024) \times 1.8 \%$ & $=1.84 \%$ \\
\hline \multirow[t]{2}{*}{$\mathrm{R}_{\mathrm{Dd}}=$} & Business risk (DOL) premium & $=(1+h) \times d$ & $=(1+0.024) \times 2.7 \%$ & $=2.76 \%$ \\
\hline & & & Post-tax $K_{d}=$ & $7.01 \%$ \\
\hline
\end{tabular}

\subsubsection{Cost of Equity}

Similarly, cost of equity can also be calculated thus:

$\mathrm{K}_{\mathrm{e}}=[\mathrm{h}+\{(1+\mathrm{h}) \times(\mathrm{r}+\mathrm{d}+\mathrm{f})\}] \div(1-\mathrm{t})$

$\mathrm{K}_{\mathrm{e}}=[0.024+\{1.024 \times(0.018+0.027+0.01)\}] \div 0.60$

$\mathrm{K}_{\mathrm{e}}=13.387 \% \approx 13.39 \%$ uity:

Equation 2 can be broken down into three parts to get the following tax-adjusted components of cost of eq-

\begin{tabular}{llll}
$\mathrm{R}_{\mathrm{Eh}}=$ & $\begin{array}{l}\text { Post-tax inflation pre- }=\mathrm{h} \div(1-\mathrm{t}) \\
\text { mium on equity }\end{array} \mathrm{R}_{\mathrm{Er}}=\begin{array}{l}\text { Rate of return (sacrifice } \\
\text { value) on equity funds ad- } \\
\text { justed for tax }\end{array}$ & $=(1+\mathrm{h}) \times \mathrm{r} \div(1-\mathrm{t})$ & $4.00 \%$ \\
$\mathrm{R}_{\mathrm{Ee}}=\begin{array}{l}\text { Post-tax business and fi- } \\
\text { nancial (DOL }+ \text { DFL) } \\
\text { risk premiums }\end{array}$ & $\mathrm{K}_{\mathrm{e}}$ & $3.07 \%$ \\
& & $6.31 \%$ \\
\hline
\end{tabular}

\subsubsection{Weighted Average Cost of Capital (WACC)}

Weighted average cost of capital is calculated using the following equation:

$\mathrm{K}_{\mathrm{a}}=\left[\left(\mathrm{K}_{\mathrm{d}} \times \mathrm{D}\right)+\left(\mathrm{K}_{\mathrm{e}} \times \mathrm{E}\right)\right] \div[\mathrm{D}+\mathrm{E}]$

The following notations are used in equations 1,2 and 3, as well as in the resulting calculations:

$$
\begin{array}{ll}
\mathrm{d}=\text { premium for operating (business risk) } & \mathrm{K}_{\mathrm{d}}=\text { cost of debt } \\
\mathrm{D}=\text { ratio of debt in total project outlay } & \mathrm{K}_{\mathrm{e}}=\text { cost of equity } \\
\mathrm{E}=\text { ratio of equity in total project outlay } & \mathrm{r}=\text { real risk-free interest rate } \\
\mathrm{f}=\text { premium for financial risk } & \mathrm{t}=\text { tax rate } \\
\mathrm{h}=\text { inflation premium } & \mathrm{K}_{\mathrm{a}}=\text { WACC }
\end{array}
$$

Summary of the components of cost of debt, cost of equity and weighted average cost of capital are presented in Table 3. 
Table 3

Total and Component-wise Cost of Funds

\begin{tabular}{|l|c|c|c|c|c|}
\hline \multicolumn{1}{|c|}{ Sources } & Weights & Sacrifice value & $\begin{array}{c}\text { DOL \& DFL } \\
\text { Risk Premiums }\end{array}$ & $\begin{array}{c}\text { Capital } \\
\text { Maintenance }\end{array}$ & Total \\
\hline Debt: Post tax $\mathrm{K}_{\mathrm{d}}$ & 0.50 & $1.84 \%$ & $2.76 \%$ & $2.40 \%$ & $7.008 \%$ \\
Equity: $\mathrm{K}_{\mathrm{e}}$ & 0.50 & $3.07 \%$ & $6.31 \%$ & $4.00 \%$ & $13.387 \%$ \\
\hline $\mathrm{K}_{\mathrm{a}}=$ WACC & 1.00 & $2.46 \%$ & $4.54 \%$ & $3.20 \%$ & $10.197 \%$ \\
\hline
\end{tabular}

It should be noted that the risk-free rate of return compensates the sacrifice value of investment funds, business and financial risk premiums compensate the DOL and DFL risks, and inflation premium takes care of capital maintenance. Debt and Equity are assigned equal weights of $50 \%$ as each contributed $\$ 54,000$ towards the $\$ 108,000$ outlay of the example project.

\section{Calculation of Net Value Added}

We present below calculation of NVA in four steps while simultaneously demonstrating the drawbacks of the NPV method.

1. In the first step we subtract the project's debt cash flows from the project's cash flows to get cash flows that exclusively belong to the stockholders.

2. In the second step we separate the stockholders' cash flows into three parts according to their end-use. They are equity servicing (representing the returns expected by stockholders), capital maintenance (covering inflationary effect and capital recovery) and net surplus (value creating) cash flows.

3. In the third step we deal with the discount rate applicable to equity holder's cash flows. We break down the total cost of equity into three parts: (a) a rate that ensures retention of capital (inflation effect), (b) an expected risk-free rate, and (c) expected business and financial risk premiums.

4. In the fourth and final step we calculate NVA by discounting the stockholders' net surplus cash flows with the cost of equity. Care is taken in the discounting process by not assigning the power of time $(n)$ to the risk premium portion of the cost of equity, as risk premium is not expected to grow exponentially over time.

The design of debt instrument for funding the project has a bearing on the net market capitalization. We examine this issue while discussing the impact of capital structure theory on cost of equity. The remaining part of the paper is devoted to solving the example following the four steps outlined above. The second and third steps are carried out simultaneously.

\subsection{Calculating Stockholders' Cash Flow Stream}

In the NPV method project's cash flows are discounted at WACC adhering to the principle of separation of financing from investment decisions. The resultant NPV does not measure wealth creation in terms of net market capitalization. So, it loses validity. As a first step of improvement in the calculation of NVA we separate stockholders' cash flows by subtracting debt cash flows from the project's cash flows. Table 4 shows the separation of project's cash flows into debt servicing and stockholders' cash flows assuming repayment of debt at the end of the project's life of five years. 
Table 4

Calculation of Stockholders' Cash Flow Stream and its Conventional NPV When Debt is Repayable at the End of the Project Life

\begin{tabular}{|c|c|c|c|}
\hline Year & Project Cash Flows (in \$) & Debt Cash Flows (in \$) & $\begin{array}{c}\text { Stockholders' Cash Flows } \\
\text { (in \$) }\end{array}$ \\
\hline 0 & $-108,000$ & 54,000 & $-54,000$ \\
1 & 30,000 & $-3,784 *$ & 26,216 \\
2 & 30,000 & $-3,784$ & 26,216 \\
3 & 30,000 & $-3,784$ & 26,216 \\
4 & 30,000 & $-3,784$ & 26,216 \\
5 & 20,000 & $-57,784$ & $-37,784$ \\
\hline DR & $\mathrm{K}_{\mathrm{a}}=10.20 \%$ & $\mathrm{~K}_{\mathrm{d}}=7.01 \%$ & $\mathrm{~K}_{\mathrm{e}}=13.39 \%$ \\
\hline NPV & $-1,001$ & 0 & 3,195 \\
\hline
\end{tabular}

Note: DR = Discount Rate

$* \$ 3,784=\$ 54,000 \times 7.01 \%$.

When stockholders' cash flows are discounted at the cost of equity of $13.39 \%$, the resulting NPV showed a totally different result of $\$ 3,195$ (shown in column 4) than the $\$-1,001$ (shown in column 2 ) under the conventional NPV mechanism. This adequately proves the point that the conventional NPV suffers from the limitations emanating from faulty discounting procedure.

Table 5 shows the impact of different debt repayment schedules on the net present value of stockholders' cash flow stream when discounted at the $\mathrm{K}_{\mathrm{e}}$ of $13.39 \%$. Later, debt and its repayment structure are considered in project evaluation to enable us to tap the fullest potential of value maximization under the NVA method.

Table 5

Net Discounted Values of Stockholders' Cash Flow Stream Under Different Debt Repayment Patterns

\begin{tabular}{|c|c|c|c|c|c|}
\hline \multirow{2}{*}{ Year } & \multicolumn{2}{|l|}{ Debt Repayment Options (discounted at $\mathrm{K}_{\mathrm{e}}$ of 13.39\%) } \\
\cline { 2 - 6 } & $\begin{array}{c}\text { 50K installment at the } \\
\text { end project life* (in \$) }\end{array}$ & $\begin{array}{c}\text { 25K Equal } \\
\text { installments in } \\
\text { last 2 years (in \$) }\end{array}$ & $\begin{array}{c}16 \text { 2/3K Equal } \\
\text { installments in } \\
\text { last 3 years (in \$) }\end{array}$ & $\begin{array}{c}12.5 \mathrm{~K} \text { Equal install- } \\
\text { ments in } \\
\text { last 4 years (in \$) }\end{array}$ & $\begin{array}{c}10 \mathrm{~K} \text { Equal } \\
\text { ments install- } \\
5 \text { years (in \$) }\end{array}$ \\
\hline 0 & $-54,000$ & $-54,000$ & $-54,000$ & $-54,000$ & $-54,000$ \\
1 & 26,216 & 26,216 & 26,216 & 26,216 & 15,416 \\
2 & 26,216 & 26,216 & 26,216 & 12,716 & 16,173 \\
3 & 26,216 & 26,216 & 8,216 & 13,662 & 16,929 \\
4 & 26,216 & -784 & 9,477 & 14,608 & 8,686 \\
5 & $-37,784$ & $-8,872$ & 739 & 5,554 & 8,443 \\
& & & & & $-1,007$ \\
\hline NPV & 3,195 & 2,276 & 1,275 & & \\
\hline
\end{tabular}

* See last column of Table 4

\subsection{Apportionment and Discounting of Stockholder's Cash Flow Stream}

Stockholders' share of project's cash flows needs to be appropriated according to its end-use. Three different end-uses of stockholders' cash flows are identified as follows:

1. Equity servicing cash flows relate to the required rate of return on the funds invested by equity holders. These include risk-free rate of return plus business and financial risk premiums payable to stockholders.

2. Capital maintenance cash flows relate to that portion of stockholders' cash flows earned every year and earmarked separately for avoiding erosion of capital. Inflation and capital recovery allowances are considered in determining the capital maintenance cash flows. 
3. Net surplus is the balance of stockholders' cash flow stream after meeting the requirements of interest returns and capital maintenance cash flows. Net surplus alone can add value to the firm.

Table 6 gives appropriation of stockholders' cash flow stream under the assumption that debt is repaid at the end of project life. It should be noted that the capital recovery allowance is calculated on payback basis. Stockholders' cash flow stream, after meeting the servicing obligations (of debt and equity adjusted for inflation) during the initial years is fully appropriated for the capital recovery. The net surplus is recognized only after the full recovery of capital is made in this process. In Table 6, we can see that by the third year, equity capital is fully recovered, leaving for the first time a net surplus of $\$ 10,926$. The inflation component of $4.0 \%$ is taken out from the total cost of equity of $13.39 \%$ resulting in the reduced rate of $9.39 \%$. This rate is used in determining the discounted value of equity servicing cash flows. As net surplus alone creates value to the stockholders we discount it at the total cost of equity of $13.39 \%$. Stockholders would expect same return including maintenance of capital on the amount of net surplus if they invest it in a similar risk class firm.

Table 6

Appropriation of Stockholders' Cash Flow Stream and basic Calculations With Regular Discounting Mechanism \{i.e. Power of Time (exponential growth) Assigned to all the Returns Related Components of Cost of Equity\}

\begin{tabular}{|c|c|c|c|c|c|c|c|}
\hline \multirow{4}{*}{ Year } & \multirow{4}{*}{$\begin{array}{c}\text { Project Cash } \\
\text { Flow (in\$) }\end{array}$} & \multirow{4}{*}{$\begin{array}{c}\text { Debt } \\
\text { Cash Flow } \\
\text { Repaid } \\
\text { @ Y5 (in \$) }\end{array}$} & \multicolumn{5}{|c|}{ Equity holders' Cash Flow Stream (in \$) } \\
\hline & & & \multirow{3}{*}{$\begin{array}{c}\text { Total } \\
\text { stockholders' } \\
\text { cash flow }\end{array}$} & \multicolumn{4}{|c|}{ Appropriation of Total } \\
\hline & & & & \multirow{2}{*}{$\begin{array}{c}\text { Equity } \\
\text { Servicing }\end{array}$} & \multicolumn{2}{|c|}{ Capital Maintenance } & \multirow[t]{2}{*}{ Net Surplus } \\
\hline & & & & & $\begin{array}{c}\text { Inflationary } \\
\text { Effect }\end{array}$ & $\begin{array}{c}\text { Capital } \\
\text { Recovery }\end{array}$ & \\
\hline 0 & $-108,000$ & 54,000 & $-54,000$ & & & $-54,000$ & \\
\hline 1 & 30,000 & $-3,784$ & 26,216 & 5,069 & 2,160 & 18,987 & 0 \\
\hline 2 & 30,000 & $-3,784$ & 26,216 & 3,287 & 1,401 & 21,529 & 0 \\
\hline 3 & 30,000 & $-3,784$ & 26,216 & 1,266 & 539 & 13,485 & 10,926 \\
\hline 4 & 30,000 & $-3,784$ & 26,216 & 0 & 0 & 0 & 26,216 \\
\hline 5 & 20,000 & $-57,784$ & $-37,784$ & 0 & 0 & 0 & $-37,784$ \\
\hline DR & $10.20 \%$ & $7.01 \%$ & $13.39 \%$ & $9.39 \%$ & $4.00 \%$ & $4.00 \%$ & $10.20 \%$ \\
\hline NPV & $-1,001$ & $\mathbf{0}$ & 3,195 & 8,348 & 3,851 & $-3,851$ & 3,195 \\
\hline
\end{tabular}

The amount of equity servicing of $\$ 5,069$ in the first year equals $9.39 \%$ on the initial equity capital of $\$ 54,000$. In subsequent years the amount is calculated by applying the same rate on the declining balance of equity capital. In the first year $\$ 18,987$ of the equity capital is recovered as can be seen in the capital recovery column. The second year's equity-servicing amount of $\$ 3,287$ is calculated by applying the rate of $9.39 \%$ on $\$ 35,013$ (the difference between $\$ 54,000$ and $\$ 18,987$ ). Thus, equity servicing at $9.39 \%$ and capital maintenance at $4.00 \%$ together account for the total cost of equity 13.39 percent. Net surplus cash flows are discounted at the total cost of equity of 13.39 percent.

\subsection{Using Proper Discounting Mechanism in Calculating NVA:}

The problem of assigning the power of time $(n)$ to risk premium component of $\mathrm{K}_{\mathrm{e}}$ in the discounting process would still persist. The NVA method goes into properly identifying components of stockholders' cash flows as well as components of cost of equity so that other limitations of the conventional discounting can be fully addressed.

Conventionally, Eq. 4 given below is applied in determining the discount factor thus:

$$
\frac{1}{(1+r)^{n}}
$$


Power of time (n) assigned to the function (1+r) in the process of discounting needs to be scrutinized. Cost of equity $\left(\mathrm{K}_{\mathrm{e}}\right)$ represented by $r$ is broken down into three components, $R_{\mathrm{Eh}}, R_{\mathrm{Er}}$, and $\mathrm{R}_{\mathrm{Ee}}$, and Eq. 4 is rewritten in the following manner:

$$
\left\{1+\left(R_{E h}+R_{E r}+R_{E e}\right)\right\}^{n}
$$

where: $\mathrm{R}_{\mathrm{Eh}}=$ rate of return required to maintain original capital from erosion

$\mathrm{R}_{\mathrm{Er}}=$ risk-free return required by the stockholders

$\mathrm{R}_{\mathrm{Ee}}=$ risk premiums required to cover business and financial risks

Does the power of time (n) assigned to all the three components of the cost of equity in equation 5 not distort the present value calculation? Rate of return required by investors $\left(\mathrm{R}_{\mathrm{Er}}\right)$ and rate of return required for maintenance of capital $\left(\mathrm{R}_{\mathrm{Eh}}\right)$ are subject to exponential growth over time, but risk premium portion $\left(\mathrm{R}_{\mathrm{Ee}}\right)$ of cost of equity capital is not a function of time and hence is not subject to exponential growth. Therefore, power of time should not be assigned to this part of the equation 5 . Recognizing this, equation 5 is modified below as equation 6 :

1

$$
\left(1+\mathrm{R}_{\mathrm{Eh}}\right)^{\mathrm{n}} \times\left(1+\mathrm{R}_{\mathrm{Er}}\right)^{\mathrm{n}} \times\left(1+\mathrm{R}_{\mathrm{Ee}}\right)
$$

Net surplus present value of $\$ 3,195$ shown in Table 6 is based on the application of equation 5, where net surplus is discounted at the total cost of equity of $13.39 \%$, which was assigned the power of time. This gives us erroneous value creation result. Applying equation 6 to discount net surplus results in values given in Table 7. It shows the present value of net surplus, now called as NVA, of $\$ 1,909$ according to the proper choice of rate and discounting mechanism.

\begin{tabular}{|c|c|c|c|c|c|c|}
\hline \multirow{3}{*}{ Year } & \multicolumn{6}{|c|}{ Equity holders' Cash Flows (given debt repayment at Y5) (in \$) } \\
\hline & \multirow[b]{2}{*}{ Total } & \multicolumn{5}{|c|}{ Appropriation of Total } \\
\hline & & $\begin{array}{c}\text { Equity } \\
\text { Servicing }\end{array}$ & $\begin{array}{c}\text { Capital } \\
\text { Maintenance }\end{array}$ & $\begin{array}{c}\text { Capital } \\
\text { Recovery }\end{array}$ & $\begin{array}{c}\text { Net } \\
\text { Surplus }\end{array}$ & $\begin{array}{c}\text { PV of } \\
\text { Net Surplus }\end{array}$ \\
\hline 0 & $-54,000$ & & & $-54,000$ & & \\
\hline 1 & 26,216 & 5,069 & 2,160 & 18,987 & 0 & 0 \\
\hline 2 & 26,216 & 3,287 & 1,401 & 21.529 & 0 & 0 \\
\hline 3 & 26,216 & 1,266 & 539 & 13,485 & 10,926 & 8,343 \\
\hline 4 & 26,216 & 0 & 0 & 0 & 26,216 & 18,675 \\
\hline 5 & $-37,784$ & 0 & 0 & 0 & $-37,784$ & $-25,110$ \\
\hline$D R$ & $13.39 \%$ & $9.39 \%$ & $4.00 \%$ & $4.00 \%$ & $13.39 \% *$ & \\
\hline NPV & 3,195 & 8,348 & 3,851 & $-3,851$ & 1,909 & 1,909 \\
\hline
\end{tabular}

Table 7

Calculation of NVA at Appropriate Discount Rates with Proper Discounting Mechanism

* Power of time is not assigned to the risk-premium portion of cost of equity while the other two components of the cost of equity carried the power of time as per Eq. 6 .

Under the conventional NPV method of evaluation, this investment proposal would be rejected because of the negative NPV of $\$ 1001$ (see Table 6, column 2). As can be seen in the sixth column of Table 7, it actually has the potential of adding positive net value of $\$ 1,909$. The NVA of $\$ 1,909$ is more appropriate than the present value of $\$ 3,195$ as the former has resulted from the appropriate discounting mechanism. The present value based on equation 5 could be greater or lesser than the present value based on equation 6 depending upon the size and pattern of 
net surplus cash flows.

\section{Different Capital Structure Theories and Different Debt-Repayment Plans}

The NVA calculation implicitly assumes NI theory of capital structure, which postulates that the cost of equity does not change with the reduction in the firm's debt-equity ratio, while overall cost of capital, $\mathrm{K}_{\mathrm{a}}$ declines. However, the conventional NPV method is based on the implicit assumption of NOI theory of capital structure advocated by Durand (1952), and Modigliani and Miller (1958). It states that the average cost of funds, $\mathrm{K}_{\mathrm{a}}$ remains constant at all levels of the firm's debt-equity ratio. Therefore project's cash flows are discounted at a constant rate of $\mathrm{K}_{\mathrm{a}}$, usually referred to as the weighted average cost of capital (WACC). If we continue with that assumption it would imply that the risk-premium component of the cost of equity would decrease when some portion of debt is retired. However, if the debt is retired at the end of the project the cost of equity does not change. That was what we assumed so far. Let us examine the NVA calculations under the assumption of NOI theory, as then only it will be fair to compare the NVA method with the conventional NPV method.

If we assume the NOI theory, the cost of equity will decline with the reduction in the debt portion of the total capital employed in the project. In our example $\mathrm{K}_{\mathrm{a}}$ will remain at $10.20 \%$ even when debt is repaid before the expiration of project life. Let us solve Eq. 3 for cost of equity capital separately for each year. Using $\mathrm{K}_{\mathrm{a}}$ of $10.20 \%$, and $\mathrm{K}_{\mathrm{d}}$ of $7.01 \%$ and changing debt-to-equity ratio as per a given repayment plan gives us the cost of equity for each year during the project life. Subtracting from the total cost of equity the capital maintenance and sacrifice value $\left(R_{E h}\right.$ and $\mathrm{R}_{\mathrm{Er}}$ ) components provides us risk premium component of cost of equity. Table 8 gives calculated values of yearwise risk-premium component of cost of equity for alternative debt-repayment options, together with the other constant portions of cost of equity as well as total cost of equity over the period of five years.

Table 8

Values of Risk-Premium and Resultant Cost of Equity under Different Debt-Repayment Options under the NOI Theory (figures in \%)

\begin{tabular}{|c|c|c|c|c|c|c|c|c|c|c|c|c|c|c|c|}
\hline \multirow[b]{3}{*}{ 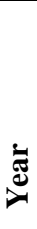 } & \multicolumn{15}{|c|}{ Debt Repayment Options } \\
\hline & \multicolumn{3}{|c|}{$\begin{array}{l}\text { \$50K lump sum at } \\
\text { the end project life }\end{array}$} & \multicolumn{3}{|c|}{$\begin{array}{l}\text { \$25K Equal } \\
\text { installments in the } \\
\text { last } 2 \text { years }\end{array}$} & \multicolumn{3}{|c|}{$\begin{array}{c}\$ 162 / 3 K \text { Equal } \\
\text { installments in the } \\
\text { last } 3 \text { years }\end{array}$} & \multicolumn{3}{|c|}{$\begin{array}{c}\$ 12.5 K \text { Equal } \\
\text { installments in the } \\
\text { last } 4 \text { years }\end{array}$} & \multicolumn{3}{|c|}{$\begin{array}{l}\text { \$10K Equal } \\
\text { installments in } \\
\text { all } 5 \text { years }\end{array}$} \\
\hline & $\begin{array}{c}\mathbf{R}_{\mathrm{Eh}+} \\
\mathbf{R}_{\mathrm{Er}}\end{array}$ & $\mathbf{R}_{\mathrm{Ee}}$ & $\mathbf{K}_{\mathrm{e}}$ & $\mathbf{R}_{\mathrm{Eh}+} \mathbf{R}_{\mathrm{Er}}$ & $\mathbf{R}_{\mathbf{E e}}$ & $\mathbf{K}_{\mathrm{e}}$ & $\begin{array}{c}\mathbf{R}_{\mathrm{Eh}+} \\
\mathbf{R}_{\mathrm{Er}}\end{array}$ & $\mathbf{R}_{\mathbf{E e}}$ & $\mathbf{K}_{\mathrm{e}}$ & $\begin{array}{c}\mathbf{R}_{\mathrm{Eh}+} \\
\mathbf{R}_{\mathrm{Er}}\end{array}$ & $\mathbf{R}_{\mathrm{Ee}}$ & $\mathbf{K}_{\mathbf{e}}$ & $\begin{array}{c}\mathbf{R}_{\mathrm{Eh}+} \\
\mathbf{R}_{\mathrm{Er}}\end{array}$ & $\mathbf{R}_{\mathbf{E e}}$ & $\mathbf{K}_{\mathrm{e}}$ \\
\hline 0 & 7.07 & 31 & $\overline{3.39}$ & 7.07 & 6.31 & 13.39 & 7.07 & 6.31 & 13.39 & 7.07 & 6.31 & 13.39 & 7.07 & 6.31 & 13.39 \\
\hline 1 & 7.07 & 1 & 13 & 7.07 & 6.3 & .39 & 7.07 & 6.31 & 13.39 & 7.07 & 6.31 & 13.39 & 7.07 & 6.31 & 13.39 \\
\hline 2 & 7.07 & 6.31 & 13.39 & 7.07 & 6.31 & 13.39 & 7.07 & 6.31 & 13.39 & 7.07 & 6.31 & 13.39 & 7.07 & 5.68 & 12.75 \\
\hline 3 & 7.07 & 6.31 & 13.39 & 7.07 & 6.31 & 13.39 & 7.07 & 6.31 & 13.39 & 7.07 & 5.52 & 12.59 & 7.07 & 5.04 & 12.11 \\
\hline 4 & 7.07 & 6.31 & 13.39 & 7.07 & 6.31 & 13.39 & 7.07 & 5.25 & 12.32 & 7.07 & 4.72 & 11.79 & 7.07 & 4.40 & 11.47 \\
\hline 5 & 7.07 & 6.31 & 13.39 & 7.07 & 4.72 & 11.79 & 7.07 & 4.19 & 11.26 & 7.07 & 3.92 & 10.99 & 7.07 & 3.76 & 10.84 \\
\hline
\end{tabular}

Now, let us examine the NVA figures under both the theories of capital structure for different repayment options. Since we have used the same steps in calculating the NVA, detailed calculations are not shown here. Table 9 gives the final results of NVA calculated under the assumptions of NOI theory (i.e. $\mathrm{K}_{\mathrm{e}}$ declines with reduction of debt-equity ratio and $\mathrm{K}_{\mathrm{a}}$ remains constant) and $\mathrm{NI}$ theory (i.e. $\mathrm{K}_{\mathrm{e}}$ remains constant at all debt-equity levels and $\mathrm{K}_{\mathrm{a}}$ declines) under different debt repayment options, as per the conventional and appropriate discounting mechanisms. 
Table 9

NVAs with Different Debt Repayment Options under NI and NOI Theories Using Conventional as well as Appropriate Discounting Mechanisms

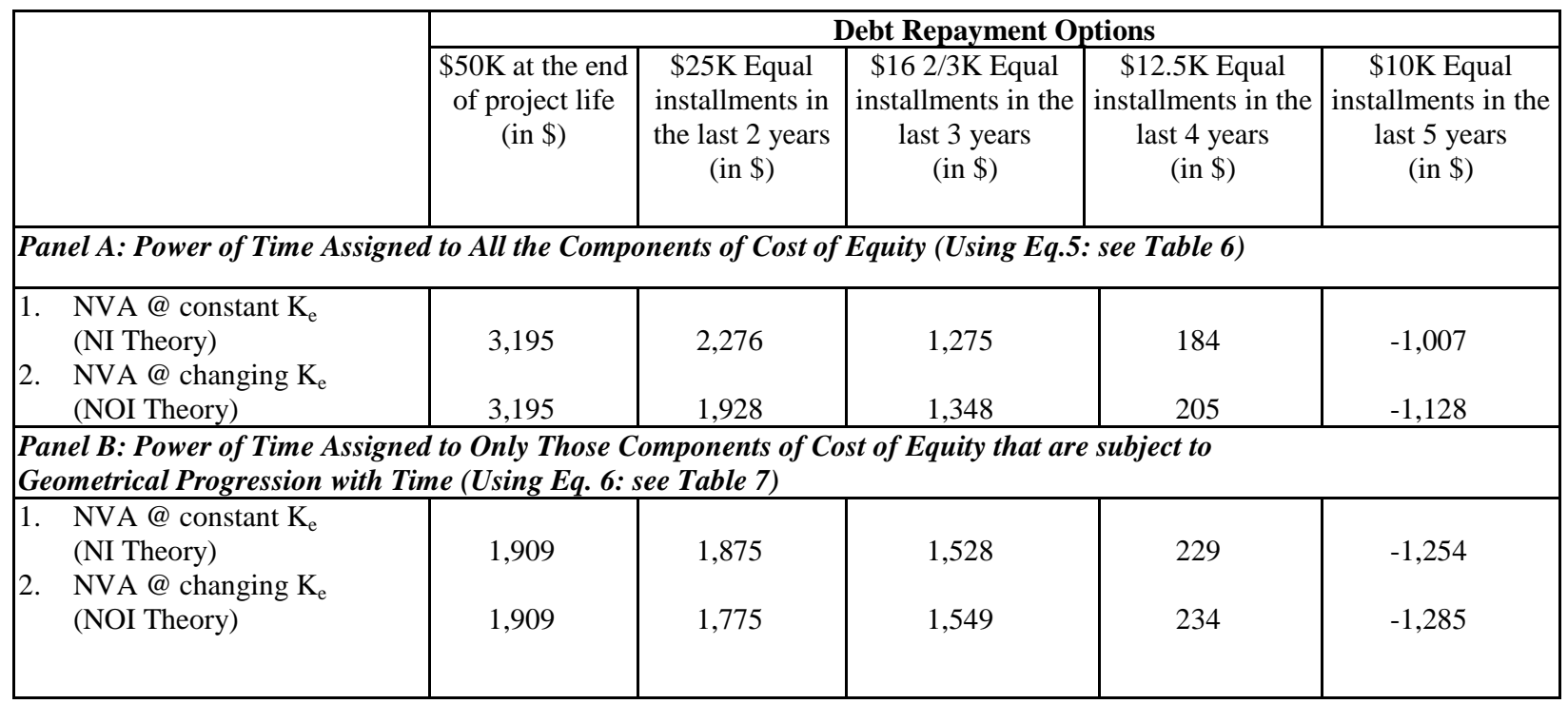

Panel A of Table 9 is given only for showing comparison of values when faulty (conventional) discounting mechanism is used. Panel B gives NVA figures based on the application of equation 6, where discounting mechanism is devoid of limitations discussed earlier.

The conventional NPV amount of negative $\$ 1,001$ calculated earlier will remain the same under any debtrepayment option as it assumes the principle of independence of financing decision from investing decision. But the same project actually creates value for stockholders under the NVA framework. The value creation is different under different debt-repayment plans. For the example project, the firm should take debt and repay it at the end of the project life as NVA is maximized at $\$ 1,909$ as can be seen in column 2 of Table 9. Those who believe in NI theory will also select the same option in this example. As can be expected, value addition under the NVA measure is more pronounced with higher corporate tax rates, greater use of financial leverage and lower cash inflows in the project. The point of focus is that firms must take financing decision in the context of projects under evaluation and measure NVAs for the attainment of the value maximization objective.

A decision-maker may like to get an answer to the question whether NI or NOI theory is valid. Many academicians agree on the traditional theory of capital structure. There exists an optimal debt-equity level for a firm under given circumstances. That is a range of capital structure in which $\mathrm{K}_{\mathrm{a}}$, the WACC will be the lowest. Addition of financial distress and agency costs to Modigliani and Miller's corporate tax model and Miller's (1977) extended personal tax model resulted in what is now called as trade-off model of capital structure. Here the marginal costs and benefits of debt financing are balanced against each other, and the result is an optimal capital structure that falls somewhere between zero and hundred percent of debt. The asymmetric information theory of capital structure advocated by Meyers (1984) recognizes that firm managers have better information than most investors, and postulates that firms should maintain a reserve borrowing capacity so that they can always borrow on reasonable terms rather than have to sell new common stock at the wrong time (following Donaldson's (1961) pecking order of corporate financing.)

Presently, most finance experts believe that an optimal capital structure that minimizes a firm's WACC and maximizes its value exists, but that it changes over time as firm's operations and investors' preferences change. They also believe that the relationship between a firm's value/WACC and leverage is flat over a range, so deviations from the optimal capital structure can occur without materially affecting its WACC or stock price. It is also true 
those firms that establish the optimal debt-equity ratio will also maintain some reserve borrowing capacity to take advantage of good investment opportunities without having to issue new equity at lower prices. Therefore, repayment of debt of a project may have no bearing on the WACC, or on the cost of equity. They may, more or less, remain constant for the firm.

The point in question is not which theory is appropriate or at what debt-equity level cost of capital is the least, but surely that debt, at any given cost, can be structured for repayment to create value. This value creation from debt structuring can be measured along with the project's potential for creating value. This is in addition to the basic issue that NVA addresses, namely, discounting the right cash flow stream, at right discount rate and using right discounting mechanism. These points give a distinct edge to the NVA concept over the much-revered NPV concept.

\section{Implications and Suggestions for Future Research}

The NVA method questions the basic logic of the NPV method, which has been accepted for decades as the best method for evaluating capital projects for the attainment of the corporate goal of wealth maximization. Since the firms have become conscious about value creation with market demanding shareholder value maximization, the NVA method suggested in this paper will initiate a renewed interest in linking corporate financial objective of stockholders' wealth maximization with investment decisions. Practitioners and researchers both would find this method interesting as it provides logical measure for the value creation. The NVA method would change the way projects are evaluated by firms and institutional financiers. Firms will be able to evaluate debt-structuring options not only in light of the repaying potential of a project's cash flows but also from the angle of value creation opportunity that may emanate from the synergic combination of investment and financing decisions. Thus, NVA would allow a firm to integrate its financing as well as investment decisions for maximum value creation.

As long as investing public depends on accounting information, including operating cash flow data, about the year that ended, application of NVA in any immediate empirical research related to stock market behavior would not be expected. However, investment analysts could make the best use of NVA by applying it to firms' announcement of investment and financing plans. Use of NVA would place them in a better position to estimate the true value of firms and guide the market. In the long run, it is hoped that public disclosure norms might change in favor of disclosing such information that may allow the investors interpret the true value creation potential of firms.

The concept of NVA is expected to lead research into measuring components of capital that would lead to meaningful application of theory in practice. The concept of EVA would gain further momentum after researchers reexamine it in terms of NVA framework. That would possibly work as an explainable link between the EVA and MVA concepts, which in turn would explain the practices of value maximizing firms. That would hopefully lead researchers in search of better lead indicators explaining long-term stock price behavior.

\section{Summary}

Stockholder wealth maximization is the well-accepted corporate financial objective. Corporate decisions must align with the corporate objective of shareholder value creation and wealth maximization. The term wealth recognizes the time value of money and also the risk-taking in decision-making by the firm. Present methods for evaluation of capital projects do not fully meet the stockholder wealth maximization criteria. NVA method suggested in this paper is aimed at remedying the limitations of the NPV technique.

NVA can be calculated by going through the four steps. First, debt-related cash flows are subtracted from the project's cash flows to get stockholders' cash flows. Then the stockholders' cash flows are apportioned into three components; namely, (a) equity servicing cash flows, (b) capital-maintenance cash flows and (c) net surplus cash flows. The net surplus cash flows are discounted at the cost of equity. Power of time is not assigned to the riskpremium portion of the cost of equity capital while discounting the stockholders' (net surplus) cash flows. Other two components of cost of equity carry the power of time as they are subject to exponential growth over time. This gives us a proper mechanism to discount net surplus cash flows without defects. The discounted value of net surplus cash flow stream so obtained is the NVA. 
NVA shows the value added to the net market capitalization of the firm. Firms should accept a project if its NVA is positive. Recollect that NVA is sensitive to debt structuring. Hence NVA method enables the firms to integrate investing as well as financing decisions into a single coherent exercise, which can be validly justified in attaining the goal of value creation and stockholder wealth maximization.

\section{References}

1. Brigham, E. F., Gapenski, L.C., and Daves, P.R., Intermediate Financial Management, $5^{\text {th }}$ ed. and $6^{\text {th }}$ ed., Fortworth: The Dryden Press, 1996 and 1999.

2. Donaldson, Gordon, Corporate Debt Capacity: A Study of Corporate Debt Policy and the Determination of Corporate Debt Capacity, Boston: Harvard Graduate School of Business Administration, 1961.

3. Hamada, Robert S., "Portfolio Analysis, Market Equilibrium, and Corporation Finance", Journal of Finance, Vol. 24, pp. 13-31, March 1969.

4. Lintner, J., "The Valuation of Risk Assets and the Selection of Risky Investments in Stock Portfolios and Capital Budgets", Review of Economics and Statistics, Vol. 47, pp. 13-37, February 1965.

5. Modigliani, F. and Miller, M.H., "Corporate Income Taxes and the Cost of Capital: A Correction", American Economic Review, Vol. 53, pp. 433-443, June 1963.

6. Miller, M.H., "Debt and Taxes", Journal of Finance, Vol. 32, pp. 261-275, May 1977.

7. $\quad$ Myers, S.C., "The Capital Structure Puzzle", Journal of Finance, Vol. 39, pp. 575-592, July 1984.

8. Patel, Bhavesh M., Project Management: Strategic Financial Planning, Evaluation and Control, New Delhi: Vikas Publishing House, 2000.

9. Sharpe, W.F., "Capital Asset Prices: A Theory of Market Equilibrium under Conditions of Risk", Journal of Finance, Vol. 19, pp. 425-442, September 1964.

10. Tuttle, D. L., and Litzenberger, R.H., "Leverage, Diversification, and Capital Market Effects on a RiskAdjusted Capital Budgeting Framework", Journal of Finance, Vol. 23, pp. 427-443, June 1968. 
Notes 